\title{
Annotating the environment. Heritage and new technologies
}

\author{
Peter van Mensch
}

\author{
Based on a lecture held at "Museums of the \\ future", Copenhagen, 13 June 2005
}

\begin{abstract}
This article attempts to make a general inventory of the different initiatives - by institutions as well as private persons - to increase access and interpretation of the environment as mindscape, as network(s) of lieux de mémoire charged with historical and collective memory.
\end{abstract}

Museology is about musealisation, which basically is the creation of heritage. In our society, musealisation is to a high degree institutionalised. A wealth of professional institutions define heritage, i.e. define memory. This is what Halbwachs (1992) refers to as historical memory. But there is also heritage that is experienced as collective memory by groups of people themselves; heritage that is not, or at least not yet, institutionalised. Part of this collective memory is connected with places and things: lieux de mémoire. These lieux de mémoire form multi-layered networks. One place might be part of different networks, i.e. part of the collective memory of different social groups. It might be possible that such place is already recognised as historical memory, but this could well be only one layer of meaning. Modern technology appears to provide new possibilities to increase access and interpretation, but also to bridge the gap between histo- rical memory and collective memory, without the collective memory being alienated ("stolen") from those whose memory it is.

New Museology has always been concerned about the attribution of meaning and significance, and the question of who is in control of this attribution. One of the manifestations of New Museological practice is the ecomuseum. An examination of the range and nature of current ecomuseums worldwide suggests that regional cultural identity (and a pride in it), a sense of community, the need for economic regeneration and the potential loss of "heritage" are the main driving forces in the creation of ecomuseums (Davis 1999). The driving forces behind the application of new technologies in the heritage field seem to be comparable.

De Varine (1988) provided a four-point plan for ecomuseums or community-centred museums. He identified four principal objectives: 
a as an object and data bank for the community

b to serve as an observatory of change (and to help the community react to changes)

c to become a laboratory - a focal point for meetings, discussions, new initiatives

$\mathrm{d}$ a showcase - revealing the community and its region to visitors.

The same objectives can be recognised among new initiatives which can be identified as materials of a virtual ecomuseum. The overarching concept is cultural biography. Rooijakkers uses this term in reference to the traces of man in the landscape by way of settlements, reclamations, roads and other (infra)structures. These structures are the keys to presenting the various lifestyles that may differ according to time, place and social or cultural groups. The material culture of domestic utensils, implements, buildings and works of art bears tangible witnesses of these lives, which are meaningful only in their ecological and cultural contexts. Consistent focus is the relation of man with his surrounding world. This includes the life-cycles of individuals, human beings of flesh and blood, as they condensate - seen from a long-term perspective - into accumulated histories of families, neighbourhoods, communities and regions (Rooijakkers 1999). The landscape as a mindscape, i.e. a mental category instrumentalized by people to give meaning to the world in which they live.

\section{RECORDING STORIES}

The Museum Amstelkring (also known as "Ons' Lieve Heer op Solder" = Our Lord in the Attic) is a small museum in the historical centre of Amsterdam. This 17th-century canal house was in 1661 transformed into a secret
Roman Catholic church, in a period when public avowing of this religion was forbidden in Holland. In 1888, the building and its interior was musealised. The present museum uses the history of the building to discuss the history of Roman Catholicism in the Netherlands. In 2004 the museum organised the exhibition "Van Doop tot Dood. Verhalen op Solder" (From Christening till Death. Stories in the Attic). During this exhibition, visitors were asked to contribute by sharing a personal story concerning the seven sacraments (Oud \& Oostdam 2005). Objects related to these stories were photographed on a so-called "Verhalen Altaar" (story altar). The collected stories were presented on a special website (www.verhalenopsolder.nl). The project followed a new trend among museums to use oral history as component of exhibitions (Chew 2002).

Imagine IC (Imagine Identity and Culture) is a centre for the visual representation of $\mathrm{mi}$ gration and cultures, located in Amsterdam Southeast. Imagine Identity and Culture is the first cultural organization in the Netherlands to highlight the culture and identity of migrants as seen from their own perspective. It invites people to describe their history and culture by means of various activities. These stories are used to create exhibitions, audio-visual programs and digital productions for both newcomers and residents (Seriese \& Tangkau 2003).

In 2000, Stefan Olivier started the Bruxelles nous appartient/Brussel behoort ons toe (Brussels belongs to us) project. The project aims to create a biography of the city by collecting stories of its citizens. People are invited to interview a fellow citizen. This interview, or rather dialogue, is shared via the project's bilingual website (www.bna-bbot.be).

In 2003, the Amsterdams Historisch Mu- 
seum organised an exhibition about the people's history of the part of Amsterdam called "East". The title of the exhibition was "Het geheugen van Oost" (Memory of East). Part of the project was the creation of a website, following the same principles as the three projects mentioned earlier (www.geheugenvanoost.nl). In the meantime, the website contains more than 400 stories, related to people, artefacts and places (De Vreede 2005).

The four projects are intended to give people the opportunity to share their stories and their heritage. Although there might be some curatorial intervention, people are basically in control of the memory they want to share. Participation and exchange is facilitated by the structure (interface) provided by the organiser. Surplus value results from the possibility of interaction between the stories. The "Brussels belongs to us" and "The memory of East" projects provide materials for a virtual biography of the city or a neighbourhood. The Imagine IC and "Stories in the Attic" projects focus on the collective memories of people with shared experiences. Through the stories, personal identities are linked with collective identities.

\section{PSYCHOGEOGRAPHY}

Many of the stories collected by aforementioned projects relate to places. Artists have long been fascinated by the urban (or rural) fabric of personal lieux de mémoire or the absence of it (the "amniotic fluid" of the Surrealists). Francesco Careri (2002) has described in detail how actual and virtual structures in the city played a role in Dada, Futurism, Surrealism, Situationism and Land Art. Situationist Guy Debord created in 1957 his "Guide Psy- chogéographique de Paris", a map showing the city as filtered by subjective experience, "measuring" on oneself and in comparison with others the affections and passions that take form by visiting places and listening to one's own inner impulses (Careri 2002: 102).

New technologies, such as television, prompted Lucio Fontana in 1952 to initiate the "Manifesto del Movimento Spaziale per la televisione":

For the first time throughout the world, we Spatialists are using television to transmit our new forms of art based on the concepts of space, to be understood from two points of view: the first concerns spaces that were once considered mysterious but that are now known and explored, and that we therefore use as plastic material. The second concerns the still unknown spaces of the cosmos - spaces to which we address ourselves as data of intuition and mystery, the typical data of art as divination. For us, television is a means that we have been waiting for to give completeness to our concepts. We are happy that this Spatial manifestation of ours is being transmitted from Italy - a manifestation destined to renew the fields of art. It is true that art is eternal, but it has always been tied down to matter, whereas we want it to be freed from matter. Through space, we want it to be able to last a millennium even for a transmission of only a minute. Our artistic expressions multiply the lines of the horizon to the infinite and in infinite dimensions. They are a form of research for an aesthetic in which a painting is no longer painted, a sculpture no longer sculpted, and in which the written page leaves behind its typographical form. We Spatialists feel ourselves to be the artists of today, since the conquests of technology are now at the service of the art we profess (Bloem 2005).

The Situationist's interest in psychogeography and the Spatialist's adoption of new technologies return in a series of contemporary pro- 
jects in which artists explore the conscious and unconscious layers of urban geographies. Thanks to new locative media and a rising interest in social issues among many artists, psychogeographic works are exploding around the world. A major US instigator this time is Glowlab, a New York collaborative founded in 2002 that stages and sponsors a variety of projects (www.glowlab.com). In 2005, Canadian artist Jillian Mcdonald created a website presenting a variety of psychogeographic projects: "Location is Everything" (rhizome.org/art/exhibition/location_is_everything/home.html). The artists in "Location is Everything" have all mapped personal or collective experiences, some informed by external factors like weather data or pop-culture references, and some allowing the map itself or local residents to inform them. As a painter might pull imagery from the paint, the map as a bird's-eye view is a locative tool that allows artists to playfully or poetically free up information about physical and psychological space.

In 2003, Brigitte Bélanger created with her team (Bellissima) an "Emotioneel Stadsplan" (Emotional City Plan) of Amsterdam. Via an interactive map (www.emotioneelstadsplan.nl), stories are connected with specific places or objects (trees). One can select personal stories on the basis of eight emotions (joy, sadness, pride, shame, guilt, sorrow, anger and fear), or eighteen themes (such as birth, death, love, change, inspiration, etc.).

In 2004, students of LIACS Media Lab (University of Leiden) created a "Trading Places" website (www.trading-places.info). It is based on personal associations one may have with other cities while in Amsterdam. The site suggests city trips in Amsterdam starting from people's perception of temporarily being in another place for a couple of moments. "Not only the place itself, neither the buildings nor the people are crucial for that reminiscence, but also other conditions are essential. Maybe the heavy rain makes you remember how lost you where at that city, walking alone. Or the sun was so hot that you were so glad when you found yourself a cool place to stay or made you feel like holiday. But it's not only the weather that's important for the feeling of temporarily being in another place. The season, the time, the day of the week, etc. are issues to be considered, too. Only if all the conditions match the previous experience will the city suddenly emerge and make it possible for you to travel the world."

\section{IN SITU}

In situ interpretation has its own history. Early handbooks, such as Arthur Percival's Understanding our surroundings (1978), already describe a wide range of media for urban heritage interpretation. In the 1990s, a new technology was introduced in London. Visiting London one could use one's own mobile phone and dial certain numbers to get a wide range of historical, cultural and anecdotal information. The service ("Guidephone") is no longer available, but the technology is still used in many different places. Celebrating the 200th birthday of Hans Christian Andersen, the Danish city of Copenhagen created "Hans Christian Andersens Fodspor" (Hans Christian Andersen's Footsteps - a soundwalk through the author's Copenhagen). The tour brings the visitor past 62 sites that had significance in the life and writing of Hans Christian Andersen. At all stops along the route, a sign tells about the location back then. Panels give phone numbers to call with one's mobile phone, 
bringing the audience into direct contact with the author, who - brought to life by present day actors - gives his own account of the location. In English, these sound-quotes are read and interpreted by Sir Derek Jacobi and in Danish by Lars Mikkelsen. The same tour (including the texts read by Derek Jacobi) can be done virtually on the internet (www.goldendays.dk/HcaFodspor/gd_flash_da.html).

In 2003, mobile phone-based audio tours were introduced in New York. Miles Kronby created the project Talking Street (www.talkingstreet.com), which now also offers audio tours in Boston and Washington DC. One example is the "Symbols of America" tour along the Washington Mall, narrated by Larry King. In addition to Larry King's lively narration, one can hear expert interviews, dramatic readings, eyewitness accounts, local voices and original music.

In some projects, PDAs are used to replace mobile telephones (Bishop 2005), but the latest generation of mobile phones offers new possibilities, especially when fitted with a GPS module. Global Positioning System (GPS) available since 2000 - makes it possible to have information available at the right time and place. The Waag Society (Amsterdam) started in February 2005 a citygame using mobile (UMTS) phones and GPS technology for students aged 12-14. In the Frequency 1550 mobile game, students are transported to the medieval Amsterdam of 1550 via a medium familiar to this age group: the mobile phone. In their role as pilgrims, students navigate through the city by means of a city map of 1550. During their walk they get information about the city and events that took place. This information is provided by the Amsterdams Gemeentearchief (Municipal Archives). The students receive and carry out orders through their phones, for example making pictures.

A more advanced use of "locative media" was developed by the Mobile Bristol Centre. The centre develops digital landscapes that overlay the physical world. Walking around this landscape, the visitor can tap into the digital sounds, sights and interactions that are positioned in the landscape and activated by his presence and actions. The digital landscape is formed from a dynamic and overlapping set of mediascapes which are context-sensitive combinations of digital media and interactions created and deployed by various authors.

In April-May 2004, Mobile Bristol presented a trial version of "Riot 1831". Equipped with a backpack and a set of headphones, the visitor experiences the riots of 1831 on Bristol's Queen Square. In 1831, the Political Reform Bill was defeated in Parliament and the vote denied once more to ordinary people. The people rose up and thousands of them have filled Queen Square in the heart of the city to vent their fury. As the present day visitor walks, his movement will trigger different pieces of the play, the more he walks around the more different pieces will unravel. One hears the rioters' voices as they plunder the surrounding buildings, the flames as buildings burn, the merchants as they flee for their lives and the Dragoon Guards as they sabre-charge through the crowds cutting down the rioters. By altering his position, the visitor is in charge of who and what he hears. Art and technology have immersed him in the historical event and make it possible to shape the experience.

\section{PSYCHOGEOGRAPHY IN SITU}

In May 2005, the Museum of Copenhagen started with a series of six audio walks in the 
22 Vesterbro neighbourhood. The neighbourhood is in a period of transition. From being a working-class neighbourhood with an abundance of social problems, the area is undergoing a massive renovation that has attracted students and younger families. The audio walks follow this transition through the eyes of six persons with a personal relation with the area. Their stories can by downloaded, but $\mathrm{Mp} 3$ players are also provided by the museum (located in the same area).

The Vesterbro audio walks allow storytelling and reality to meet and intermingle. For 15-40 minutes, the visitor is immersed in the world of the storyteller. This is connecting the Imagine IC and "Brussels belongs to us" projects with in situ interpretation. The in situ variant of the "Story in the Attic" and "Memory of East" projects is the Canadian [murmur] project (www.murmurtoronto.ca). In 2003, Shawn Micallef, James Roussel and Gabe Sawhney started a project to explore site-specific personal histories in Toronto. The project consists of posting phone numbers on signs around a neighbourhood. Those who call the number from a mobile phone can hear an anecdotal history of the site, recorded and archived by someone who wants to share the story. The number to call is posted as close as possible to the site where the event(s) took place.

A similar project of "annotating the environment" is Yellow Arrow, launched in 2004 (www.yellowarrow.org). Like [murmur] Yellow Arrow wants to "transform the human experience by changing the way people look at their environment". Participants place yellow arrows to draw attention to different locations. By sending a text message (SMS) from a mobile phone to the Yellow Arrow number beginning with the arrow's unique code, Yellow
Arrow authors essentially save a thought on the spot where they place their sticker. Messages range from short poetic fragments to personal stories to game-like prompts to action. When another person encounters the Yellow Arrow, he or she sends its code to the Yellow Arrow number and immediately receives the message of that arrow on their mobile phone. The website YellowArrow.net extends this location-based exchange, by allowing participants to annotate their arrows with photos and maps in the online gallery of Yellow Arrows placed throughout the world.

In December 2004, New York University graduate John Geraci launched Grafedia (www.grafedia.net). With Grafedia, every surface becomes potentially a web page, and the entire physical world can be joined with the Internet. Grafedia authors can make hyperlinked text at any time and any place by writing or selecting a word and adding a blue underline. It can be written anywhere - on walls, in the streets, or on sidewalks. Grafedia can also be written in letters or postcards, or, for example, on the body as tattoos. Once an instance of grafedia is identified, one can retrieve the content that is linked to the text by sending a message from a wireless device (cell phone, PDA, etc) addressed to the underlined word plus '@grafedia.net'. So, for example, if one saw a grafedia message with the word love underlined in blue, one would send a message from a wireless device to 'love@grafedia.net' to receive the linked content.

An increasing number of projects use new technologies to question the authority of heritage and art institutions. When does an object become art? What makes a landmark? Who says what counts? The projects are based on the assumption that everybody has a story, and that people themselves decide what stories 
need to be preserved. "We think people underestimate the stories they have - if something means something to you, other people want and even need to know that", as is written on the [murmur] website. "By contributing a story, you're adding your distinct voice to the public discourse and record that defines what the city is."

\section{SLOW CITY}

Shawn Micallef, one of the creators of [murmur], considers the project an antidote to guerilla marketing: "We're constantly screamed at by ads wanting you to buy stuff and do stuff, but this is actually information you want to hear. It's bubbling up through sidewalks - selling you not more stuff, but experiences and people; selling you your neighbours. This is a person, not a talking Coke machine." (Pugh 2004). Unnecessary walking, watching, listening and imagining are the heart of [murmur]. The aimless, watchful figure of the flâneur, as described by philosopher Walter Benjamin, is important to [murmur] thinking, too. According to $\mathrm{Mi}$ callef, to dial in to a [murmur] tale means to "step out of daily routine and see the city from a different angle." He adds that the group's work is "not a linear thing to be used in a set way. You can step out of the subway and hear one story or set out to go through them all." The stories are not numbered, so there is no correct or incorrect order to listening.

These ideas come close to the concept of "Slow City". Called Cittaslow in Italy, the country of its birth, Slow City is the offspring of another movement, Slow Food. The Italian Slow Food association was start- ed in 1986 in Barolo by Carlo Petrini, a writer provoked by the incursion of Americanstyle fast food chains into Rome. His manifesto bewailed the fact that we "are enslaved by speed and have all succumbed to the same insidious virus: Fast Life, which... forces us to eat Fast Foods, which diminish opportunities for conversation, communion, quiet reflection, and sensuous pleasure, thus shortchanging the hungers of the soul" (Swift 2005). In Orvieto, Italy in 1999, the Slow Cities movement held its first meeting. Their Charter of Association identifies globalization as a phenomenon that, while it offers "a great opportunity for exchange and diffusion,... does tend to level out differences and conceal the peculiar characteristics of single realities." The seven stated particular aims of cities in the Slow Cities movement include emphasizing recovery and reuse methods to "maintain and develop the characteristics of their surrounding area and urban fabric", safeguarding "autochthonous production, rooted in culture and tradition, which contributes to the typification of an area, maintaining its modes and mores and promoting preferential occasions and spaces for direct contacts between consumers and quality producers and purveyors", and promotion of "the quality of hospitality".

Oral storytelling has a long tradition of offering insight and understanding. Listening to stories as presented through [murmur] and Yellow Arrow is much like walking through the city with inhabitants who know its stories. In experiencing these stories, people can develop a new intimacy with the city's lieux de mémoire: once a story is attached to a place, that location has a new significance and can no longer be arbitrarily overlooked or forgotten. 
All projects provide material for a cultural biography of a region. Traditionally, cultural biographies are fragmented, scattered among a wide range of heritage institutions. Collective memories usually escape the interest of the visitor. Many of the projects mentioned aim at identifying collective memories and have developed methodologies to share these stories. New technologies also provide opportunities for an integrative approach of the institutionalised heritage (historical memory). An example is Sense of Place South East (www.sopse.org.uk). Sense of Place South East is a consortium of local authority museums and libraries in South East England. The SoPSE partners (Hampshire County Council, West Berkshire Council, Slough Council, Reading Borough Council and the Royal Borough of Windsor and Maidenhead) have combined to create their individual heritage websites from a shared platform using a common Content Management System that delivers the online databases. The project comprises a web portal and a series of microsites, currently including 'Greenham - a common inheritance', 'Hantsphere', 'Slough History online', 'The Huntley \& Palmers Collection' and 'Thames Pilot'. Each microsite delivers fully searchable images and information from libraries, museums, archives, local papers and a range of organizations enhanced with narrative stories.

The Identity Factory Southeast (IDentiteitsfabriek Zuid-Oost: IDZO) creates a cultural infrastructure in the Kempenland and Meijerij regions in the southeast of the North Brabant province in The Netherlands. Its infrastructure resembles "Sense of Place South East". Core is a Content Management System created to making optimal use of objects pre- sent inside (and outside) heritage institutions and of events on many stages, of values of the landscape and natural history peculiarities and of recreational and tourist facilities spread all over the area. Not the providers, but the visitors/customers are the central figures in this. They adapt the chain of providers from modules to a custom-made, personalized consumer package of products. What IDZO supplies is in fact not a product, but an infrastructure of modules that can be configured in all directions. The objective of the project is to develop a proper interface connecting the Content Management System with the visitor's own wireless device. With a GPS module, the visitor has access to all available information in situ. The information will be offered in layers, leaving the visitor to decide how far he wants to go. The system will also offer themes making it possible for the visitor to be guided through the region.

It is clear that the cultural biography of the region is first and foremost a human story which cannot be presented without the people from the region itself. Participation of the inhabitants themselves is therefore of crucial importance: they must primarily be able to identify themselves with the modules of the IDZO (an ego-documents program is therefore part of the project).

A secondary, yet important, concern is tourists "from outside". For them, a region with a sound basis for cultural activities, which people feel an affinity with and take pride in as their "own" civilization in all its shapes and forms (fine and vulgar, rural and urban Brabant and metropolitan, honourable and criminal, common and deviant, orthodox and heretical, global and local, historic and current) goes beyond the smooth image of clichés with safe stories, up to a place of genuine ex- 
perience. After all, the consumer wants a flexible, high-quality product which can be personalized in the best possible way. Clear connections between the different assets shaped by the concept of the regional cultural biography provide an essential extra value to the tourist's leisure stay. In this way, a region like Kempenland can be positioned on the cultural market with many commercial and imaginative opportunities (Rooijakkers 1999).

\section{SOCIAL SOFTWARE}

The "post-PC" era of ubiquitous computing is driven by a boom in mobile devices and information appliances that will become ever cheaper, more energy efficient, seamlessly interoperable, configurable over the Internet as well as always and optimally connected (Geser \& Pereira eds. 2004b: 27). Overall, future mobile devices are likely to have much more processing power as well as dynamic memory, multimedia accelerators that allow for a much richer visual experience, and multiple types of wireless capabilities. Multimodal interfaces will enable us to control and interact with the environment to a considerable degree and with various media in a natural and personalised way (loc. cit.: 29). This will challenge our concepts of heritage and our relation with historical and collective memories.

The examples mentioned in the present article show the potential of new technologies to bridge the gap between historical and collective memories. However, the projects are hardly interactive. One listens to stories, and in return one can add his or her own story, but there is no real person-to-person exchange of experiences. The projects could perhaps be enriched by interfaces that facilitate or encoura- ge conversational interaction. Such software 25 has been described as "social software" (Boyd 2003). According to Stowe Boyd, social software should support conversational interaction between individuals or groups including real time and "slow time" conversation, like instant messaging and collaborative teamwork spaces, respectively, should support social feedback which allows a group to rate the contributions of others, and should support social networks to explicitly create and manage a digital expression of people's personal relationships, and to help them build new ones. "Social software reflects the 'juice' that arises from people's personal interactions," writes Boyd. "It's not about control, it's about co-evolution: people in personal contact, interacting towards their own ends, influencing each other." Museology is about musealisation, but heritage is created by people. This is a collective process. Any new technology providing for access and interpretation should respect this.

\section{POSTSCRIPT}

This article benefited a lot from the work of some of my students from the Reinwardt Academie and the University of Amsterdam. Irina Leifer (Reinwardt Academy) introduced me to the Yellow Arrow project and inspired me by showing the strong affinity of [murmur] and Yellow Arrow to the Slow City movement. Karen van Hameren (Reinwardt Academie) researched web-based communities and the new definitions of heritage and identity within this context. She introduced me to the concept of "social software". Eefje de Groot (University of Amsterdam) wrote an excellent study of the "Sagensafari", exploring the notions of memory and place. The "Sagensafari" 
26 is a project to link local legends with the landscape and to experience both in an integrated way. I also thank my colleagues Theo Thomassen and Nico Halbertsma for the many discussions we had about heritage and e-Culture.

This article also benefited from the work of DigiCULT. Digital Culture (DigiCULT) is a project within the framework of the Information Society Technologies (IST) initiative, initiated by the European Commission, DG Information Society (Unit D2: Cultural Heritage Applications). Its Newsletters, Technology Watch Reports, Special Issues and Thematic Issues are invaluable resources for everyone interested in the developments that are discussed in this article.

\section{Notes}

1. The lecture in Copenhagen on which this article is based also featured a view of the future as the third question "What Future?", but any exhaustive account in written form would make this article too long.

\section{LITERATURE}

Bishop, L.: "Tour de force". Attractions Management (72). 2005.

Bloem, M.: "Fontana en het Manifesto del Movimento Spaziale per la televisione". De Witte Raaf (117): 2. 2005.

Boyd, S.: "Are you ready for social software?". Darwin Magazine 2003.

(http://www.darwinmag.com/read/050103/social.html).
Careri, F.: Walkscapes. Walking as an aesthetic practice. Editorial Gustavo Gili: Barcelona 2002.

Chew, R.: "Collected stories: the rise of oral history in museum exhibitions". Museum News 81 (6). 2002, p. 30-37.

Davis, P.: Ecomuseums. A sense of place. Leicester University Press: London 1999.

Geser, G. \& J. Pereira (eds.): Virtual communities and collaboration in the heritage sector. DigiCULT

Thematic Issue 5. DigiCULT/Salzburg Research: Salzburg 2004 (a).

Geser, G. \& J. Pereira (eds.): The future digital heritage space. An expedition report. DigiCULT Thematic Issue 7. DigiCULT/Salzburg Research: Salzburg 2004 (b).

Halbwachs, M. 1992: On collective memory. The University of Chicago Press: Chicago 1992.

Keenan, E.: Marking time. Do you ever feel like nothing really ever happened in Toronto? There's a reason

(http://eye.net/eye/issue/issue_07.01.04/city/mar king.html). 2004.

Oud, W. \& R. Oostdam: Persoonlijke verhalen in Ons' Lieve Heer op Solder. Onderzoek naar interactieve publieksbegeleiding in Museum Amstelkring, Ons' Lieve Heer op Solder. SCO-Kohnstamm Instituut: Amsterdam 2005.

Percival, A.: Understanding our surroundings. London 1978.

Pope, S.: The shape of locative media (http://www.metamute.com/look/article.tpl?IdLanguage $=1 \&$ IdPublication $=1 \& \mathrm{NrI}$ ssue $=29 \& \mathrm{Nr}$ Section=10\&NrArticle=1477). 2005.

Pugh, A.: Flâneur by phone. The [murmur] project brings cellular psychogeography to the Annex (http://www.eye.net/eye/issue/issue_08.19.04/cit y/murmur.html). 2004.

Rooijakkers, G.: "Identity Factory Southeast. Towards a flexible cultural leisure infrastructure" in Dodd, D. and Hemel, A. van (eds.): Planning cultural tourism in Europe: a presentation of theori- 
es and cases. Boekmanstichting: Amsterdam 1999, pp. 102-111. Also available at: http://www.finnica.fi/seminaari/99/luennot/rooijakk.htm.

Seriese, E. \& M. Tangkau: Verhalen vangen. Verzamelen, ontsluiten en presenteren van immaterieel cultureel erfgoed. Imagine IC: Amsterdam 2003.

Swift, N.: Slow Cities movement offers alternative to global mediocrity (http://www.citymayors.com/environment/slow_ cities.html). 2005.

Varine, H. de: 'Rethinking the museum concept' in Gjestrum, J. A. and Maure, M. (eds.) Okomuseumsboka - identitet, okologi, deltakelse. ICOM: Tromso 1988, pp. $33-40$.

Vreede, M. de (ed.): Blawwdruk. Vier musea en social inclusion, Nederlandse Museumvereniging, Amsterdam 2005.

\section{WEBSITES}

Bruxelles nous appartient www.bna-bbot.be

DigiCULT www.digicult.info

Emotioneel Stadsplan www.emotioneelstadsplan.nl

Frequency 1550 freq1550.waag.org

Geheugen van Oost www.geheugenvanoost.nl

Glowlab www.glowlab.com

Grafedia www.grafedia.net

Hans Christian Andersen Foodsteps www.goldendays.dk/HcaFodspor/gd_flash_da.ht $\mathrm{ml}$
Identiteitsfabriek Zuid-Oost www.idzo.nl
LIACS Media Lab

skynet.liacs.nl/medialab/bin/showindex

Location is Everything

rhizome.org/art/exhibition/location_is_everyt-

hing/home.html

Mobile Bristol Centre www.mobilebristol.com [murmur] www.murmurtoronto.ca

Museum Amstelkring www.museumamstelkring.nl Museum of Copenhagen www.bymuseum.dk Sense of Place South East www.sopse.org.uk Slow Cities www.cittaslow.net Talking Street www.talkingstreet.com Trading Places www.tradings-places.nl Verhalen op Solder www.verhalenopsolder.nl Vesterbro site www.flamingoeffekten.dk Waag Society www.waag.org Yellow Arrow www.yellowarrow.org

Dr. Peter van Mensch is Lecturer in Muselogy at the Reinwardt Academy. The Reinwardt Academy is the Museology Faculty of the Amsterdam school of the Arts. E-mail adress: p.vanmensch@ahk.nl. 